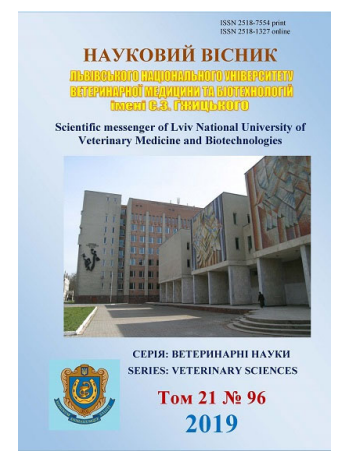

\author{
Науковий вісник Дьвівського національного університету \\ ветеринарної медицини та біотехнологій імені С.3. Гжицького. \\ Серія: Ветеринарні науки \\ Scientific Messenger of Lviv National University \\ of Veterinary Medicine and Biotechnologies. \\ Series: Veterinary sciences
}

\title{
Innovative domestic product of "Емкарвак" - vaccine against blacleg at the market of veterinary immunobiological facilities
}

\author{
P. Boyko ${ }^{1}$, B. Busol ${ }^{2}$, L. Akymenko ${ }^{3}$, O. Boyko ${ }^{4}$, B. Kurtiak ${ }^{5}$, O. Assory ${ }^{6}$ \\ ${ }^{1}$ Institute of Veterinary Medicine of NAAS, Kyiv, Ukraine \\ ${ }^{2}$ National Scientific Center "Institute of Experimental and Clinical Veterinary Medicine", Kharkov, Ukraine \\ ${ }^{3}$ State Scientific Control Institute of Biotechnology and Microorganism, Kyiv, Ukraine \\ ${ }^{4}$ Experimental Station of Epizootology of the Institute of Veterinary Medicine of the National Academy of Sciences of \\ Ukraine, Rivne, Ukraine \\ ${ }^{5}$ Stepan Gzhytskyi National University of Veterinary Medicine and Biotechnology Lviv, Ukraine \\ ${ }^{6}$ Sumy biological state factory, Sumy, Ukraine
}

Article info

Received 01.10.2019

Received in revised form 01.11 .2019

Accepted 02.11.2019

Institute of Veterinary Medicine, National Academy of Sciences of Ukraine, Donetska Str., 30, Kyiv 03151, Ukraine.

National Scientific Center "Institute of Experimental and Clinical Veterinary Medicine", Pushkinska Str., 82, Kharkov, 61023, Ukraine.

State Scientific Control Institute of Biotechnology and Microorganism Donetska, Str., 30, Kyiv, 03151,

Ukraine.

Experimental Station of Epizootology of the Institute of Veterinary Medicine of the National Academy of Sciences of Ukraine, Knyaz Volodymyr Str., 18, Rivne, 33028, Ukraine.

Stepan Gzhytskyi National University of Veterinary Medicine and Biotechnologies Lviv, Pekarska Str., 50, Lviv, 79010, Ukraine. Tel.: +38-097-698-93-71 E-mail:kurtakbohdan@gmail.com

Sumy biological state factory, Hamalia Str., 25, Sumy, 40021, Ukraine
Boyko, P., Busol, B., Akymenko, L., Boyko, O., Kurtiak, B., \& Assory, O. (2019). Innovative domestic product of "Емкарвак" - vaccine against blacleg at the market of veterinary immunobiological facilities. Scientific Messenger of Lviv National University of Veterinary Medicine and Biotechnologies. Series: Veterinary sciences, 21(96), 19-27. doi: 10.32718/nvlvet9604

The results over the test of new domestic vaccine against to the blackleg - "EMKAPBAK" was brought. The local productive strain $C$. chauvoei of $\Omega-7$ has high immunogenicity, protective capacity and create immunity duration over 9 months. The corresponding changes in regulation technological process was enable to use of the newest data in relation to immunogenicity capacity of $C$. chauvoei. In particular, duration of accumulation of microbial mass of C. chauvoei in a reactor diminished from 36-42 hours to 1618 hour, as an adsorbent is used aerosils of brand of A-300 (a production is Germany) from the calculation of $3 \pm 0.1 \mathrm{mg} / \mathrm{sm}^{3}$ culture; the supernatants was recovered by concentration of liquid after inactivation. The microbial mass of vaccine is $3.5 \pm 0.3 \times 10^{93}$. The tests of vaccine of "EMKAPBAK" showed that preparation was sterile, inactivated, harmless (a bioassay is on guinea-pigs), owns high antigen (the level of antibodies for the instilled animals presented 1:828 \pm 257 on a $21^{\text {th }}$ day after inoculation) and immunogenicity activity. The field tests of vaccine of "EMKAPBAK" showed that a vaccine owns high antigenicity, providing even in 12 months after her inoculation high level of specific antibodies (the level for the instilled animals presented 1:32 \pm 6.0 against $1: 11 \pm 3.6$ for control animals). The productive tests of the productiveexperienced series of vaccine of 'EMKAPBAK' conducted in the conditions of 22 unhappy economies of the Volyn' area on young cattle. Rejections of general (oppression, increase of temperature, loss of appetite and others like that) or changes of local character (slight swelling in place inoculation, increase of regional lymphatic knots) it was not educed. Thus, the vaccine of "EMKAPBAK" in the conditions of the field test appeared harmless and immunogenicity, able to support tense immunity at the receptive contingent of cattle during 9 months (term of supervision).

Key words: Clostridium chauvoe, blacleg, local strain, constructing of vaccine, immunogenicity, protective capacity, virulence. 


\title{
Інноваційний вітчизняний продукт “Емкарвак" - вакцина проти емфізематозного карбункулу на ринку ветеринарних імунобіологічних засобів
}

\author{
П.К. Бойко ${ }^{1}$ В.О. Бусол ${ }^{2}$, Л.І. Акименко ${ }^{3}$ О.П. Бойко ${ }^{4}$ Б.М. Куртяк ${ }^{5}$, О.Ю. Ассорі ${ }^{6}$ \\ ${ }^{1}$ Інститут ветеринарної медицини НААН, м. Київ, Украӥна \\ ${ }^{2}$ Національний науковий центр “ІЕКВМ”, м. Харків, Украӥна \\ ${ }^{3}$ Державний науково-контрольний інститут біотехнології і итамів мікроорганізмів, м. Київ, Україна \\ ${ }^{4}$ Дослідна станџія епізоотологї Інституту ветеринарної медицини НААН, м. Рівне, Україна \\ ${ }^{5}$ Львівський національний університет ветеринарної медицини та біотехнологій імені С.3. Гљсицького, м. Львів, \\ Україна \\ бДержавне підприємство “Сумська біологічна фабрика”, м. Суми, Украӥна
}

У статті наведено результати випробувань нової вітчизняної вакцини проти емфізематозного карбункулу “ЕМКАРВАК” із вітчизняного виробничого штаму С. сhаиуоеі Л-7, яка створює імунітет тривалістю понад 9 місяців. Використання новітніх даних щзодо імуногенних детермінант C. сһаиуоеі дало можливість внести відповідні зміни у регламент технологічного процесу. Зокрема, тривалість накопичення мікробної маси С. сһаиуоеі в реакторі зменшена з 36-42 год до 16-18 год; як адсорбент використано аеросил марки А-300 (виробництво Німеччина) з розрахунку $3 \pm 0,1$ мг/см ${ }^{3}$ культури; концентрування мікробної маси проводили декантуванням надосадової рідини після інактивації та адсорбування культури; кінцева концентрація мікробних тіл - 3,5 \pm $0,3 \times 10^{9}$ в $1 \mathrm{~cm}^{3}$ вакцини. Лабораторні випробування вакцини “ЕМКАРВАК» показали, щзо препарат є стерильним, інактивованим, нешкідивим (біопроба на морських свинках), володіє високою антигенною (рівень антитіл у щеплених тварин становив 1:828 \pm 257 на 21-й день після уведення вакцини) та імуногенною активністю. Польовими випробуваннями вакцини “ЕМКАРВАК” встановлено, щуо вакцина володіє високою антигенністю, забезпечуючи навіть через 12 місяців після ї̈ уведення високий рівень специфічних антитіл (рівень аглютинінів у щеелених тварин становив 1:32 \pm 6,0 проти 1:11 \pm 3,6 у контрольних тварин). Виробничі випробовування виробничо-дослідної серї вакцини “ЕМКАРВАК” провели в умовах 22 неблагополучних господарств Волинської області на молодняку великої рогатої худоби. Відхилень загального стану (пригнічення, підвищення температури, втрата апетиту тощи) або змін місиевого характеру (припухлість на місиі уведення, збільшення регіональних лімфатичних вузлів) не було виявлено. Таким чином, вакцина “ЕМКАРВАК” в умовах польового випробування виявилася нешкідливою та імуногенною, здатною підтримувати напружений імунітет у сприйнятливого контингенту великої рогатої худоби протягом 9 місяців (термін спостереження).

Ключові слова: емфізематозний карбункул, токсигенні і вірулентні властивості Clostridium chauvоеi, конструювання вакицHu.

\section{Вступ}

Актуальність теми. Незважаючи на те, що в країні донині не розроблена цілісна система розвитку агропромислового комплексу, проте у кожній області ми бачимо виникнення та успішний розвиток ферм великої рогатої худоби молочного і м'ясного напрямків і підтримку держави (Postanova vid 30 sichnya 2019). З'являються вітчизняні породи м'ясного і комбінованого напрямків, які пристосовані до нагулу на природніх пасовищах (Logosha, 2012). Природно, що цей контингент худоби потрібно захистити від збудників грунтових інфекцій, зокрема сибірки та емфізематозного карбункулу.

Аналіз останніх досліджень $і$ публікацій. Відомо, що на території всіх регіонів України прояв епізоотичного процесу емфізематозного карбункулу великої рогатої худоби та овець має постійний характер (Bojko, 1998). При цьому повторні спалахи інфекції у неблагополучних пунктах спостерігалися через десятки років (Mandygra et al., 2003). Тому питання контролю епізоотичного процесу цієї інфекції $є$ дуже актуальним. Найбільш ефективним є комплексний контроль всіх трьох ланок епізоотичного процесу (Воjko, 2008), а в неблагополучних пунктах - вакцинація сприйнятливих тварин (Kagan \& Kyryllov, 1976; Kyryllov, 2001; Bojko, 2009). 3 цією метою в Україні використовують концентровану гідрооксидалюмініє- ву формолвакцину проти емфізематозного карбункулу великої рогатої худоби і овець, яку виготовляють на Сумській державній біофабриці. Ця вакцина була розроблена у $60-\mathrm{x}$ роках минулого століття. Вона забезпечує імунітет тривалістю до 6 місяців.

Для середніх і північних широт Росії така тривалість імунітету є цілком задовільною, бо пасовищний період там триває не більше ніж пів року. В Україні тривалість пасовищного періоду є довшою. Зважаючи на суттєве глобальне потепління, тривалість пасовищного періоду в Україні зросла до 8-9 місяців. Тому для надійного захисту тварин, які випасаються, тривалість імунітету повинна бути не меншою ніж 9 місяців.

Мета роботи - дати порівняльну характеристику основних властивостей вітчизняного виробничого штаму C. chauvoei Л-7 та відзначити особливості технології виготовлення вакцини "ЕМКАРВАК”.

Завдання дослідження полягало насамперед у виділенні перспективного і вітчизняного штаму C. chauvoei, який за імуногенними властивостями не поступався б зарубіжним виробничим штамам (Bojko et al., 2008). По-друге, технологія виготовлення вакцини повинна забезпечувати повну експресію та збереження імуногенних детермінант виробничого штаму i таким чином створювати триваліший імунітет у щеплених тварин. 


\section{Матеріал і методи досліджень}

В роботі використано бактеріологічні, біологічні, біохімічні та імунологічні методи досліджень. Досліджували морфологічні ознаки, тинкторіальні, культуральні та біохімічні властивості виробничого штаму C. chauvoei Л-7 згідно з DSTU ISO 7218 (DSTU ISO 7218:2014), DSTU 8492:2015 (DSTU 8492:2015), DSTU 7937 (DSTU 7937:2006). Для вивчення біохімічних властивостей штаму використано мозкове середовище, молоко, середовище Гісса із моноцукрами i середовище токсинонакопичення (Bojko, 2003; Busol et al., 2005).

Патогенність виробничого штаму C. chauvoei Л-7 вивчали на морських свинках масою $400 \pm 50$ г з використанням добової культури $C$. chauvoei Л-7 в дозі $0,5 \mathrm{~cm}^{3}$ за ГСТУ 46.024-2002 (Galuzevyj standart Ukrayiny, 2002).

Освіження патогенних властивостей штаму проводили через організм теляти віком 3 міс., не щепленого проти будь-якого захворювання. Для цього су-

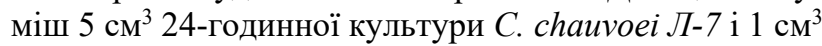
стерильного $5 \%$ розчину кальцію хлориду вводили підшкірно в ділянці лівого паху. Впродовж першої години після смерті тварини відбирали патологічний матеріал (серце, селезінка, печінка, нирки, уражена м'язова тканина) для бактеріологічного дослідження 3 метою вивчення типовості виділеної культури C. chauvoei Л-7 за морфологічними ознаками і культурально-біохімічними властивостями, виділення матрової культури (master-seed) і відбору патологічного матеріалу для тривалого зберігання.

Бактеріологічне дослідження патологічного матеріалу зводилося до вивчення морфологічних ознак і тинкторіальних властивостей $C$. chauvoei $Л-7$ у мазках-відбитках із патологічного матеріалу і препаратах, пофарбованих за Грамом, i "роздушена крапля” із 12-14-годинних культур, отриманих шляхом висіву всіх органів і тканин в середовище Кітта-Тароцці (СКТ), м'ясо-пептонний бульйон (МПБ) і на м'ясопептонний агар (МПА) (контроль на присутність аеробної мікрофлори) і тверді живильні середовища кров'яний глюкозний м'ясо-пептонний агар (КГМПА). Посіви інкубували за температури $37 \pm 0,5{ }^{\circ} \mathrm{C}$ протягом 24-48 год. Методологія проведених досліджень базується на вимогах DSTU 7198:2010 (DSTU 7198:2010), DSTU 7199:2010 (DSTU 7199:2010), DSTU 8164:2015 (DSTU 8164:2015).

\section{Результати та їх обговорення}

Із колекції виробничих, музейних і польових штамів збудника емфізематозного карбункулу, що зібрана нами впродовж кількох десятків років і нараховує 31 ізолят, нами відібрано як перспективний вітчизняний штам C. chauvoei Л-7 (Bojko et al., 2008).

Це польовий ізолят збудника емфізематозного карбункулу, виділений нами у 1980 році від трупа бугайчика віком 12 міс. Строгий анаероб. Грамлабільна (молоді культури грампозитивні, старі - грамнегативні) паличка $з$ джгутиками, яка утворює спори (рис. 1).

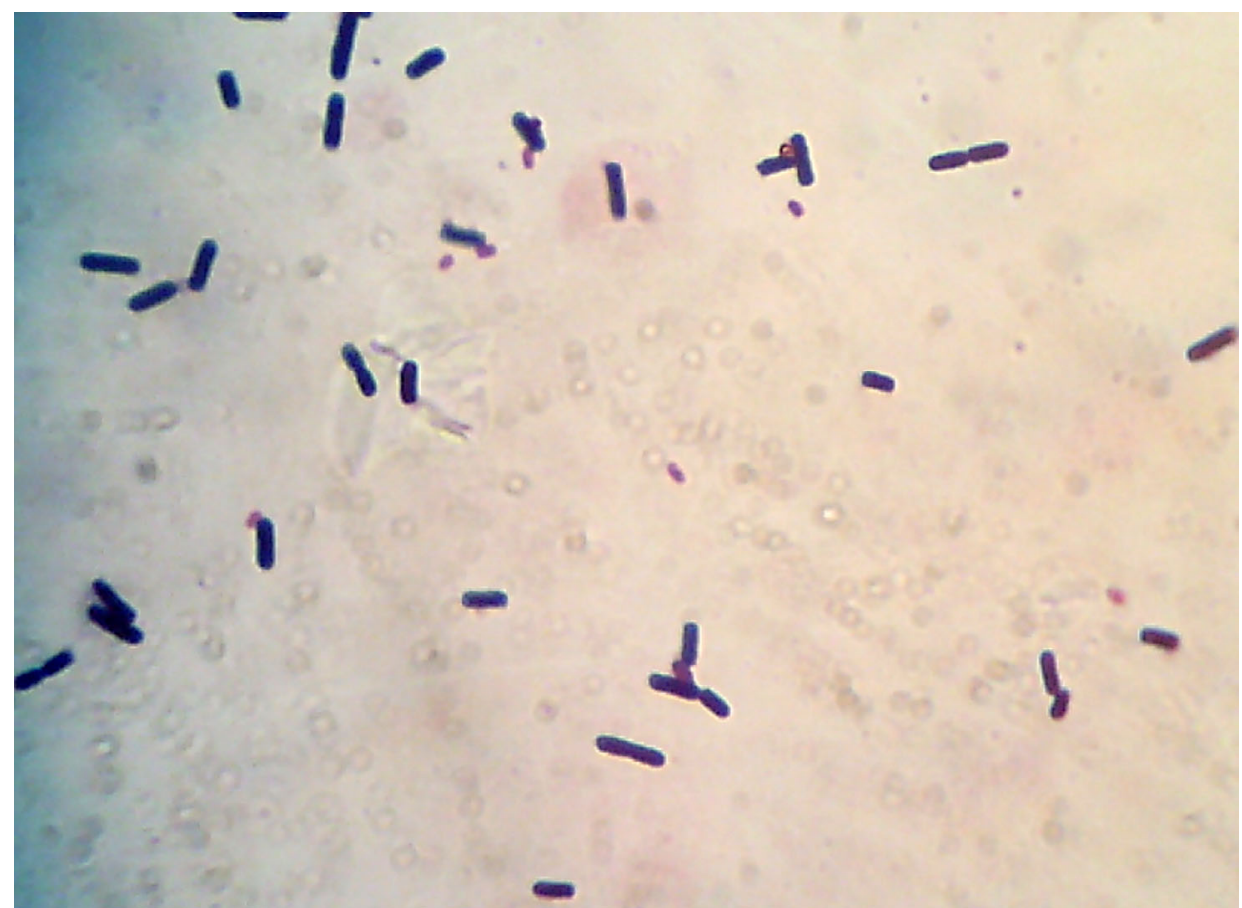

Рис. 1. Вегетативні форми штаму $\mathrm{Cl}$. chauvoei Л-7 (12-годинна культура на середовищі Кітт-Тароцці; фарбування за Грамом)

Спори розташовуються в центрі палички або підкінцево i, будучи ширшими за діаметр палички, надають мікробу форми лимона, груші, точильного каменя (рис. 2). 

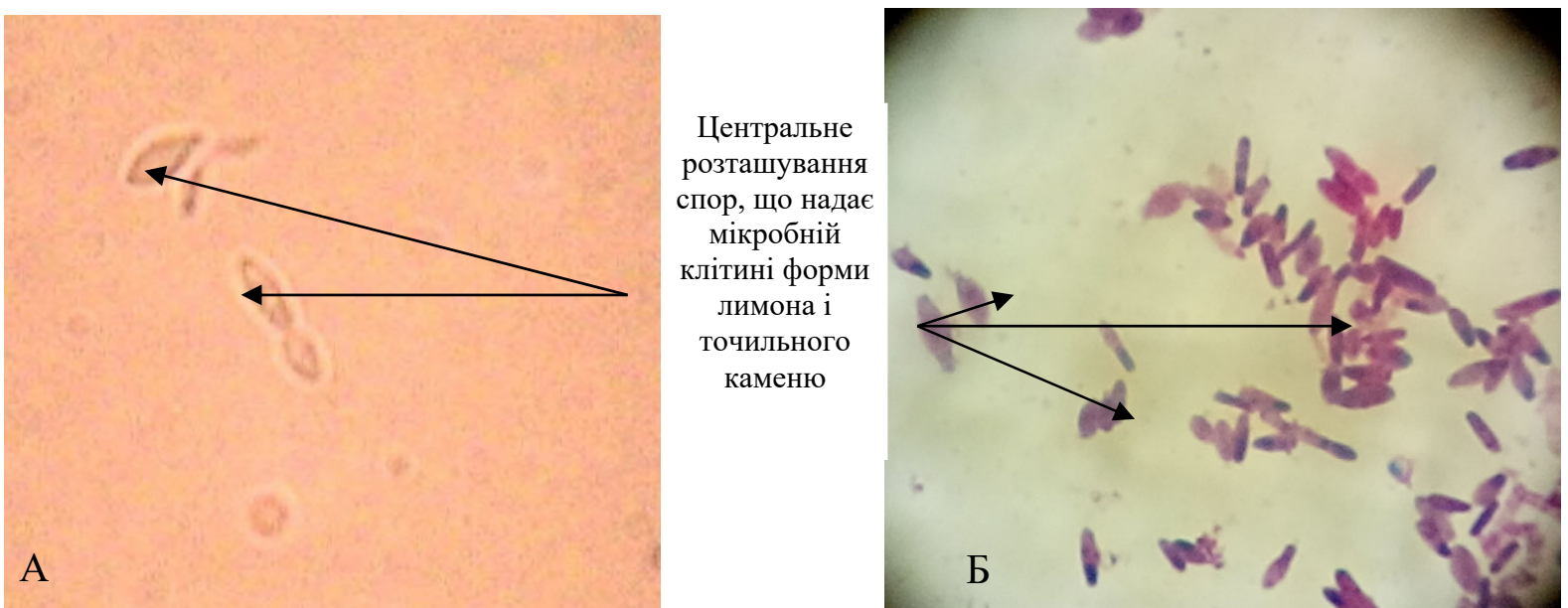

Рис. 2. 24-годинна культура на середовищі Кітт-Тароцці C. chauvoei Л-7 (А. Фазово-контрастна мікроскопія. Препарат “роздушена крапля”; Б. Фарбування за Грамом)

Газоутворення на рідких живильних середовищах незначне. Ферментує з утворенням кислоти та газу сахарозу, лактозу, маніт, глюкозу, дульцит, не розщеплює гліцерин, ізодульцит і саліцин, повільно розріджує желатину, не викликає почорніння мозкового середовища, повільно звурджує молоко.

У товщі сироваткового МПА утворює дрібні щільні круглі випуклі колонії, які розташовуються поодинці або парно у вигляді зернівки сочевиці.
На кров'яному глюкозному МПА утворює гладкі колонії двох типів. Одні за формою мають вигляд виноградного листка (якщо чашки Петрі із середовищем були недостатньо підсушені) зі значною зоною гемолізу (рис. 3), а другі мають вигляд перламутрового гудзика 3 помітною зоною прозорого гемолізу навколо колоній (рис. 4).

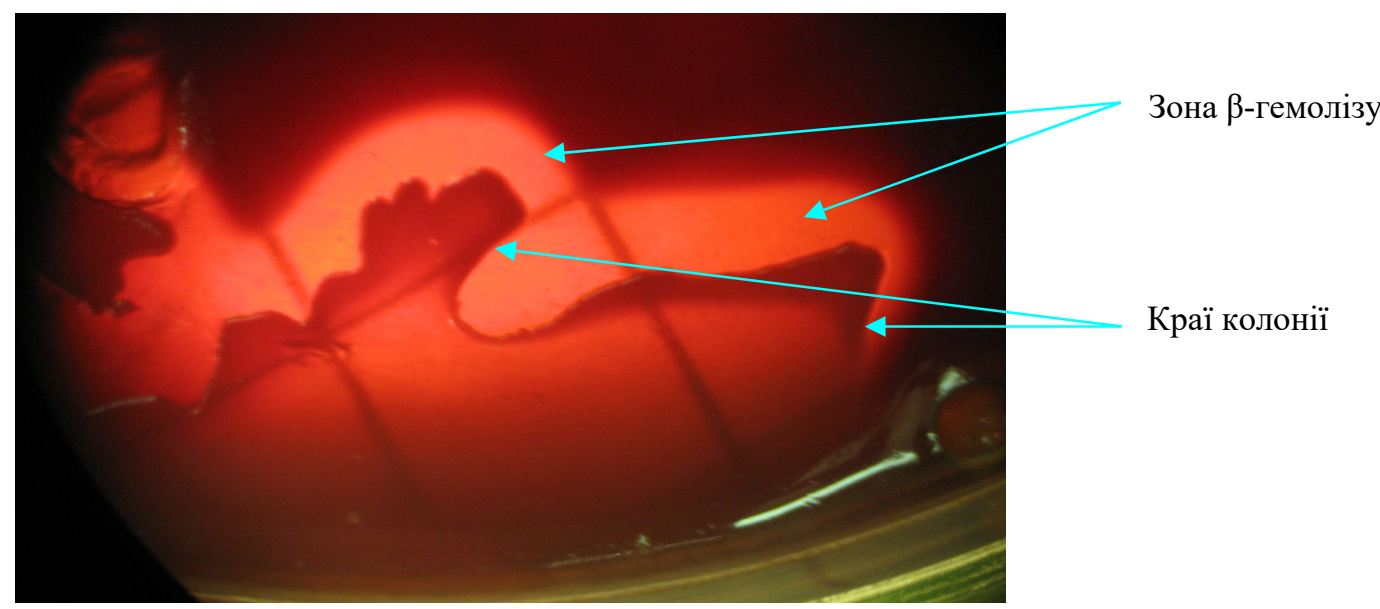

Рис. 3. Колонія 40-годинної культури C.chauvoei Л-7 на кров’яному агарі (форма виноградного листа)

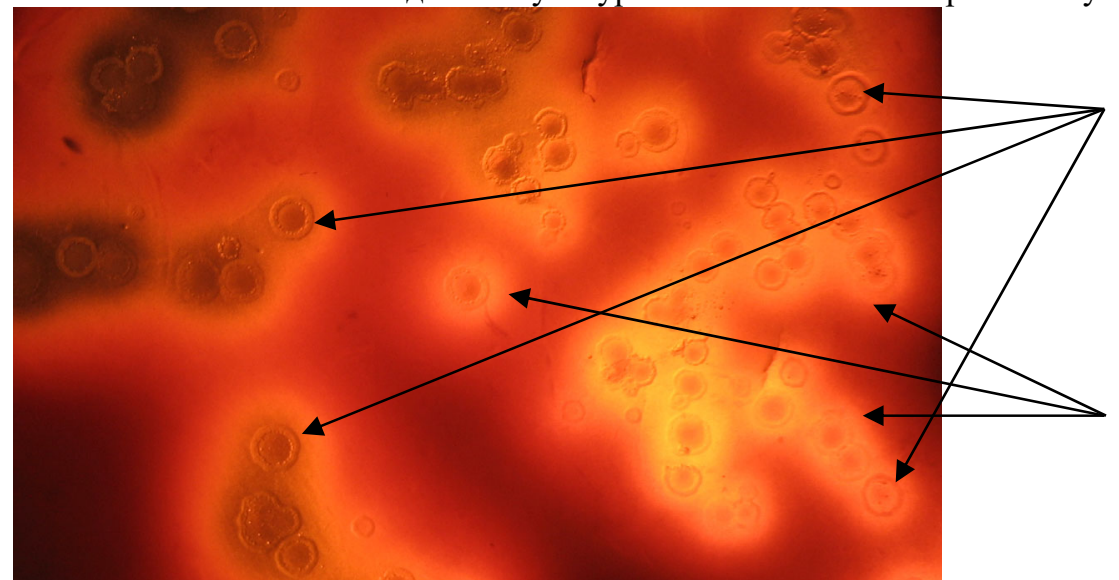

Колонії C. chauvoei

Рис. 4. Колонія 40-годинної культури C. chauvoei Л-7 на кров'яному агарі (форма перламутрового гудзика) 
Колонії молодих культур мають голубуватий колір, а старі набувають сірого забарвлення; поверхня колоній обох типів гладка, центр і краї круглих колоній дещо припідняті й у відбитих прямих променях створюють враження перламутрових гудзиків. Краї колоній оточені зоною прозорого гемолізу.

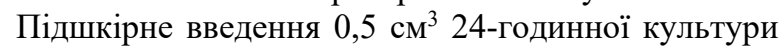
спричиняє загибель морських свинок вагою $350 \pm 50$ г через 18-28 год. 3 типовою для C. chauvoei патологоанатомічною картиною (рис. 5) - морські свинки зазвичай лежать на животі (ніби сплять), добре помітний набряк підшкірної клітковини живота, що простягається аж до підгрудка; на розрізі драглистий кров'янистий ексудат, м'язова тканина кінцівки від темно-вишневого до чорного кольору.

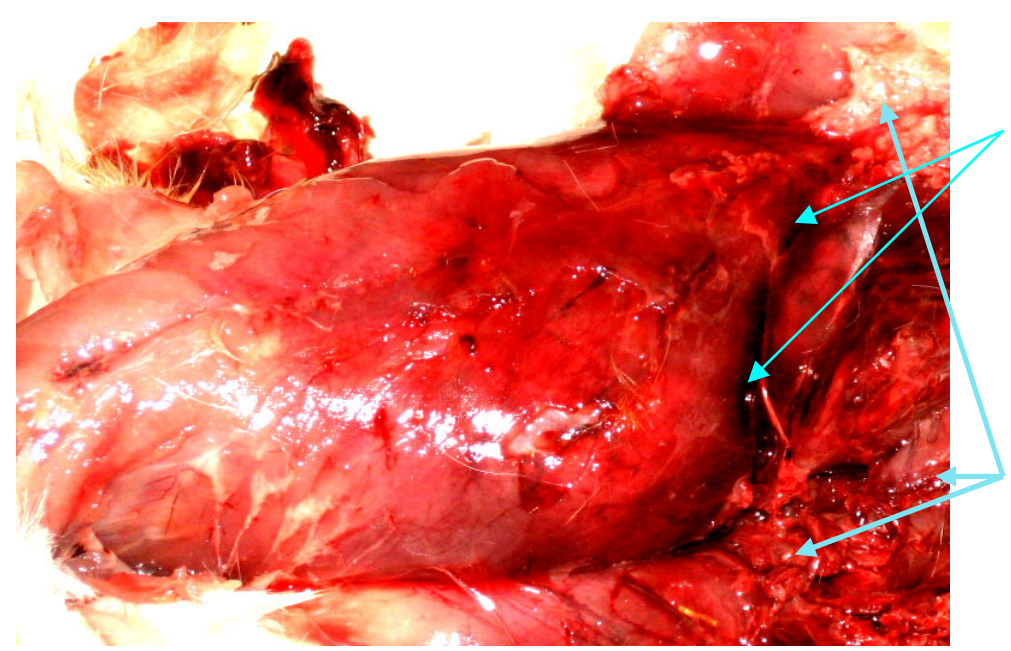

Кров'янистий ексудат у підшкірній клітковині і некротизовані тканини

Рис. 5. Зміни у підшкірній клітковині на місці уведення культури C. chauvoei Л-7.

Вивченням антигенності та імуногенності екзотоксину та антигенів вегетативних клітин $C$. chauvoei Л-7 встановлено, що визначальним фактором імуногенності $є$ концентрація та стан вегетативних клітин, тимчасом як для екзотоксину властива висока антиген- ність і незначна імуногенність (Bojko et al., 2008). Більшість авторів імуногенну силу емкарних вакцин пов'язують із джгутиковим антигеном вегетативних клітин C. chauvoei (рис. 6.) (Chandler \& Gulasekharam, 1974; Tanaka et al., 1987).

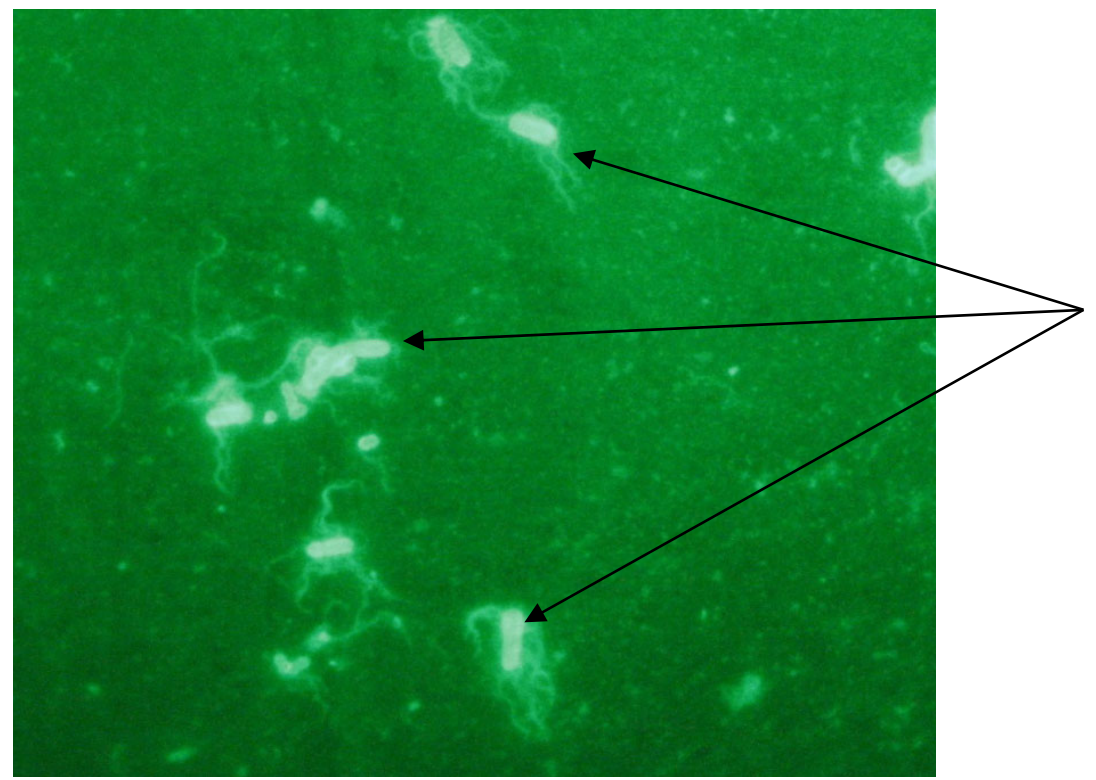

Вегетативні клітини із джгутиками

Рис. 6. Вегетативні форми штаму $\mathrm{Cl}$. chauvoei Л-7 із джгутиками (16-годинна культура на середовищі Кітт-Тароцці; непрямий варіант МФА)

Технічним регламентом 3 виготовлення інактивованої вакцини проти емфізематозного карбункулу передбачено пасажування виробничого штаму через організм сприйнятливої тварини (велика рогата худоба чи вівці) 3 метою освіження його вірулентних властивостей.
Для цього ми провели гострий дослід з поновлення патогенних та вірулентних властивостей вакцинного штаму C. chauvoei Л-7 на бугайчику сірої масті доброї вгодованості, віком 3 міс., живою масою 80 кг. Інфікування теляти проводили сумішшю 5 cм $^{3} \quad 24-$ 
годинної культури штаму із $1 \mathrm{~cm}^{3} 5 \%$ розчину кальцію хлориду, яку вводили підшкірно в ділянці паху.

Експериментальний емкар у теляти, спричинений C. chauvoei Л-7, характеризувався гострим перебігом (смерть тварини наступила через 43 год після зараження), реактивним набряком у місці розвитку патологічного процесу із порушенням функції ураженої кінцівки - кульгавість, важке пересування і вставання; температурна реакція організму у процесі розвит- ку хвороби відсутня або ж не вловлюється, а в термінальній стадії спостерігається іiі зниження; набряк уражених тканин супроводжується накопиченням у них газів із характерним тріском при натисканні, що нагадує шелест - це було підставою для української назви емкару - шелесниця; накопичення газів в уражених тканинах проявляється крепітацією і тимпанічним звуком в ділянці набряку; розвитком типових для цієї інфекції патолого-анатомічних змін (рис. 7).

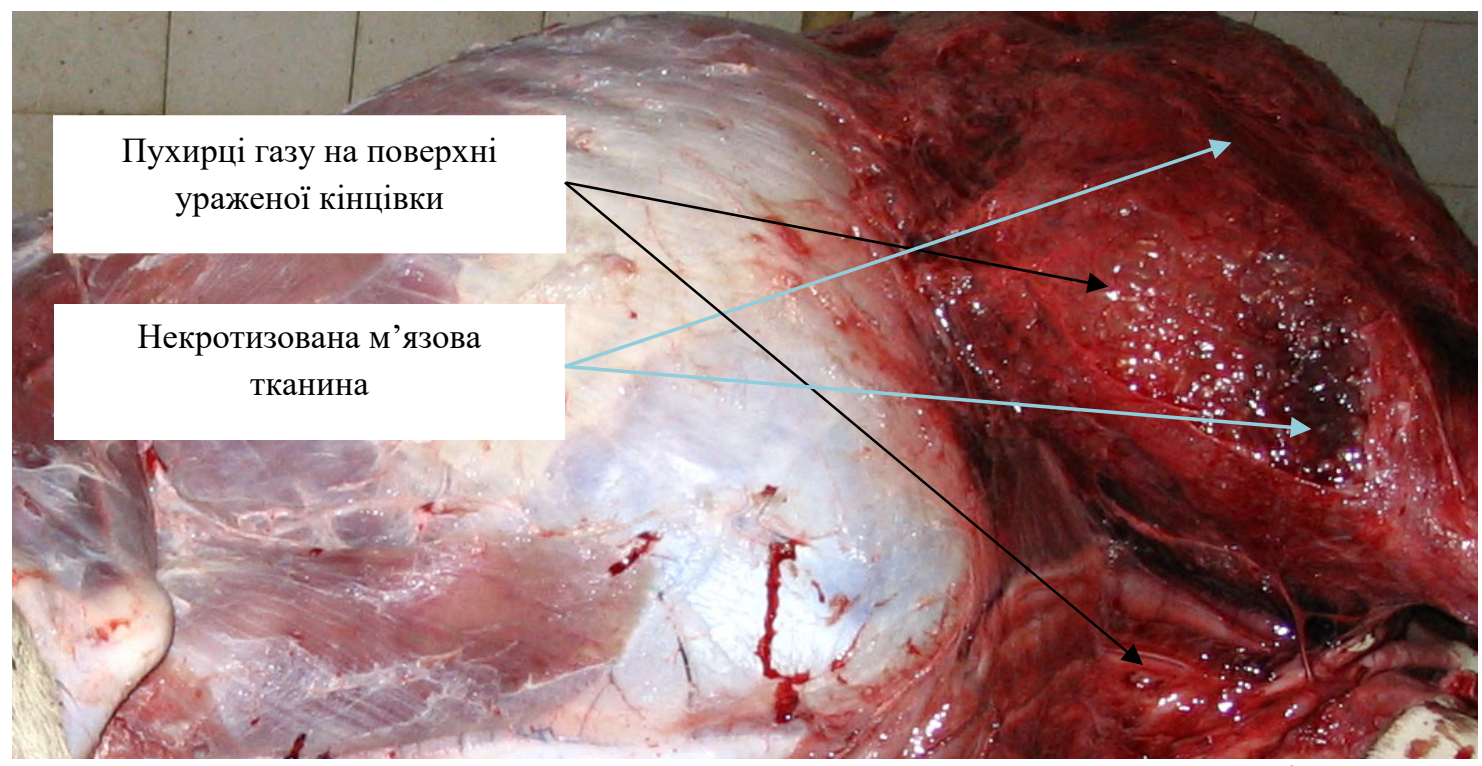

Рис. 7. Експериментальний емкар у теляти, спричинений C. chauvoei Л-7

3 рис. 7 видно, що вся задня кінцівка повністю нах дістала назви: blackleg - чорна нога або black уражена, через що й ця хвороба в англомовних краї- quarter - чорна чверть).

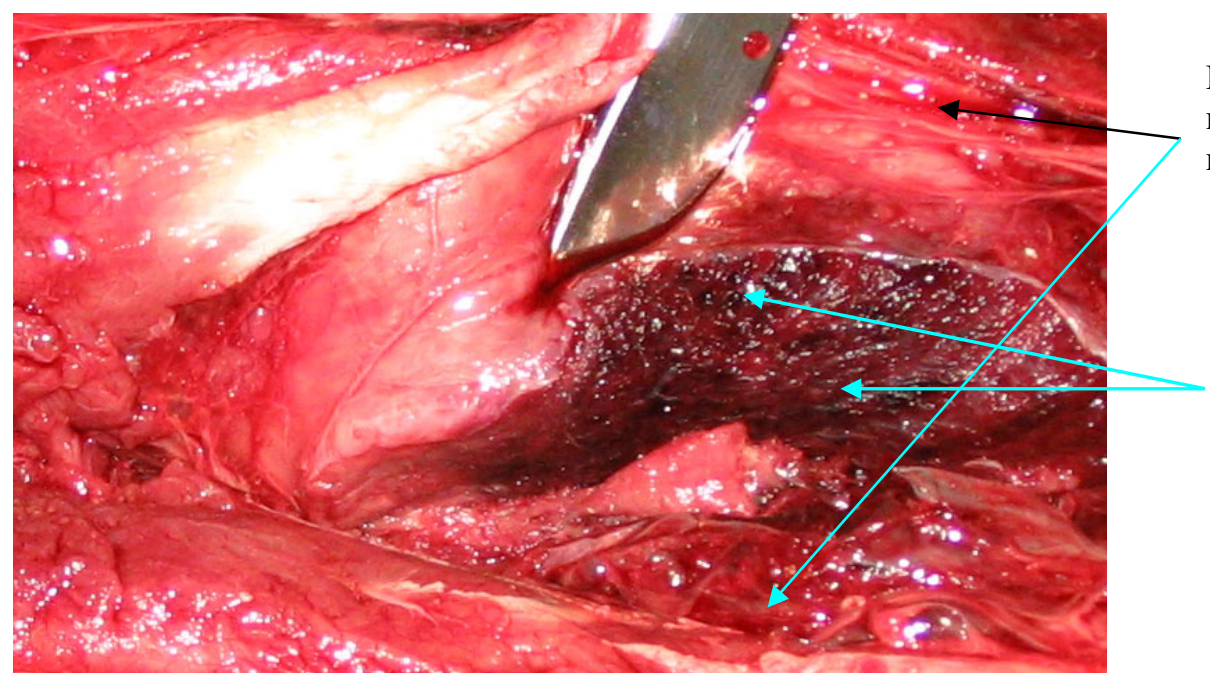

Кров’янистий ексудат, яким просочена підшкірна клітковина

Рис. 8. Експериментальний емкар у теляти, спричинений C. chauvoei Л-7 (уражені м'язи темно-вишневого і чорного кольору, сухі з крововиливами)

Таким чином, освіження штаму Л-7 з відтворенням експериментального емкару на цільовому виді тварин показало, що він володіє типовими для C. chauvoei тинкторіально-морфологічними, культурально-біохімічними, патогенними та високими вірулентними властивостями і може бути використаний як еталонний у порівняльних дослідах при депону- ванні інших ізолятів збудника емфізематозного карбункулу.

Отримані чисті культури з тканин і органів трупа теляти на середовищах Кітт-Тароцці і КГМПА були законсервовані й розфасовані у 1-мілілітрові епендорфні ампули на тривале зберігання. 
На довготермінове зберігання було закладено зразки патологічного матеріалу в гліцерині та ліофілізовану культуру C. chauvoei $Л-7$ з подальшим періодичним визначенням паспортних характеристик штаму.

Періодичність проведення штаму через організм морських свинок один раз на пів року, а через організм телят - раз на 5 років.

Відповідно до вимог FAO процедура створення партії вихідного матеріалу для виготовлення вакцини (seed-lot) поетапно має таку послідовність:

- пасаж виробничого штаму через організм сприйнятливих тварин, в якому мікроорганізм відтворює повний набір патогенних екзотоксинів та антигених й імуногенних детермінант;

- рівень протективних антигенів треба підтримувати в культурі, яка використовується для виробництва вакцини;

- повторне пасажування мікроорганізмів в штучних живильних середовищах призводить до втрати вірулентної, антигенної та імуногенної активності;

Тому культури виробничого штаму C. chauvoei можна використовувати в межах не більше ніж трьох пасажів на штучних живильних середовищах після виділення їх із патологічного матеріалу, отриманого від зараженої великої рогатої худоби, вівці або морської свинки;

- велика партія замороженого матеріалу повинна зберігатися за температури $-20^{\circ} \mathrm{C}$ або нижче (seedlots);

- seed-lots повинні надаватися для повного діапазону контрольних випробувань препарату, тобто його ідентичності, безпечності та імуногенності вакцини.

Два типи seed-lots повинні бути в наявності для забезпечення виробництва вакцина, а саме - головна або матрова (master-seed) та (work-seed) робоча культура. Ця система гарантує, що впродовж періоду зберігання фізіологічна активність штаму не зміниться так, як це може статися за його постійного культивування на штучних середовищах.

Зважаючи на результати досліджень 3 вивчення протективних властивостей антигенних детермінант C. chauvoei, які отримані різними дослідниками, в т. ч. й нами, нами внесено певні зміни у технологічний регламент промислового виготовлення інактивованої вакцини проти емфізематозного карбункулу. Зокрема, тривалість накопичення мікробної маси C. chauvoei в реакторі зменшена з 36-42 год до 16 18 год, як адсорбент використано аеросил марки А300 (виробництво Німеччина) 3 розрахунку $3 \pm$

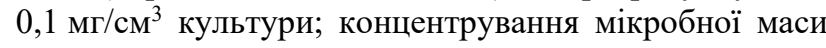
проводили декантуванням надосадової рідини після інактивації та адсорбування культури; кінцева концентрація мікробних тіл $-3,5 \pm 0,3 \times 10^{9}$ в $1 \mathrm{~cm}^{3}$ вакцини. Визначення концентрації мікробних тіл проводили в термінальній стадії інкубації за допомогою ФЕК на жовтому світлофільтрі ( $\lambda=575-590$ нм), використовуючи як стандарт бруцельозний антиген для постановки РА $з$ врахуванням відповідних коефіцієнтів, розроблених для ОСТ (оптичний стандарт каламутно- сті). При цьому ми не міняли інших технологічних параметрів виробництва вакцини.

Лабораторні випробування вакцини "ЕМКАРВАК” показали, що препарат є стерильним, інактивованим, нешкідливим (біопроба на морських свинках), володіє високою антигенною (рівень антитіл у щеплених тварин становив 1:828 \pm 257 на 21-й день після уведення вакцини) та імуногенною (вижили всі імунізовані 10 морських свинок, 4 телят i 4 ягнят 6-місячного віку після контрольного зараження суспензією із рівних частин 48-годинної культуру C. chauvoei Л-7 та 5\% стерильного розчину кальцію хлориду) активністю.

Польовими випробуваннями вакцини “ЕМКАРВАК” встановлено, що вакцина володіє високою антигенністю, забезпечуючи навіть через 12 місяців після іiі уведення високий рівень специфічних антитіл (рівень аглютинінів у щеплених тварин становив $1: 32 \pm 6,0$ проти $1: 11 \pm 3,6$ у контрольних тварин). Вакцина має виражений імуностимулюючий вплив на організм вакцинованих тварин, про що свідчать показники динаміки основних показників крові телят протягом року після щеплення вакциною “ЕМКАРВАК”, лейкоцитів, загального білка, білкового профілю сироваткових білків, підвищенням активності фагоцитів та лізоциму крові.

Виробничі випробовування виробничо-дослідної серії вакцини "ЕМКАРВАК” провели в умовах 22 неблагополучних господарств Волинської області на молодняку великої рогатої худоби. Вакцину вводили внутрішньом'язово у дозі $2 \mathrm{~cm}^{3}$. Всього було щеплено 6975 голів. Відхилень загального стану (пригнічення, підвищення температури, втрата апетиту тощо) або змін місцевого характеру (припухлість на місці уведення, збільшення регіональних лімфатичних вузлів) не було виявлено.

Всі щеплені тварини протягом літньо-табірного утримання випасалися на природних лучних пасовищах. У зв'язку з тим, що кінець осені та початок зими видалися теплими, то у всіх господарствах області, у тому числі й у неблагополучних пунктах, де було проведено щеплення тварин виробничо-дослідною серією вакцини "ЕМКАРВАК”, випасання тварин тривало включно по грудень (перші заморозки із випаданням осадів у вигляді снігу спостерігалися аж у 2-ій половині січня наступного року). Повторне щеплення сприйнятливих тварин, які залишалися на пасовищі, не проводили. Випадків захворювання на емфізематозний карбункул серед тварин, щеплених виробничо-дослідною серією вакцини, не було.

Таким чином, вакцина "ЕМКАРВАК" в умовах польового випробування виявилася нешкідливою та імуногенною, здатною підтримувати напружений імунітет у сприйнятливого контингенту великої рогатої худоби протягом 9 місяців (термін спостереження).

\section{Висновки}

1. Вітчизняний вакцинний штам $C$. chauvoei Л7, який за своїми паспортними характеристиками 
відповідає вимогам міжнародних нормативних документів, $\epsilon$ актуальним за антигенною структурою та імуногенними властивостями штамом для всієї території України.

2. Технологія виготовлення вітчизняної інактивованої вакцини проти емфізематозного карбункулу великої рогатої худоби і овець "ЕМКАРВАК" із вітчизняного виробничого штаму C. chauvoei Л-7 відповідає рекомендаціям CFR та ЄС з урахуванням певних змін: тривалість накопичення мікробної маси C. chauvoei в реакторі зменшена 3 36-42 год до 1618 год; як адсорбент використано аеросил марки А300 (виробництво Німеччина) 3 розрахунку

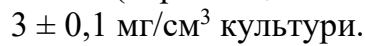

3. Виробничі випробовування дослідної серії вакцини "ЕМКАРВАК” в умовах 22 неблагополучних господарств Волинської області на молодняку великої рогатої худоби підтвердили ії нешкідливість та здатність підтримувати напружений імунітет у сприйнятливого контингенту великої рогатої худоби протягом 9 місяців.

4. Довготермінове дубльоване зберігання вакцинного штаму $C$. chauvoei Л-7 та контролювання паспортних i технологічних характеристик проводиться в депозитарії ДНКІБШМ (ліофільне висушування, заморожування за температури $-80{ }^{\circ} \mathrm{C}$ ).

Перспективи подальших досліджень включають розробку методів контролювання ефективності вакцини відповідно до вимог Державної фармакопей України та проведення постреєстраційного моніторингу.

\section{References}

"Pro zatverdzhennya Poryadku vykory`stannya koshtiv, peredbachenykh u derzhavnomu byudzheti dlya pidtrymky galuzi tvarynnycztva" Kabinet ministriv Ukrayiny. Postanova vid 30 sichnya 2019, 110 (in Ukrainian).

Bojko P.K. (1998). Do vyvchennya epizootychnogo procesu emfizematoznogo karbunkulu v Ukrayini. Naukova spadshhyna Luyi Pastera i veterynarna medycyna Ukrayiny. (Do 175-richchya vid dnya narodzhennya Luyi Pastera). Zbir. naukovykh statej. Rivne: IE UAAN, 6-12 (in Ukrainian).

Bojko, P.K. (2003). Deklaracijnyi patent na vynakhid "Seredovyshhe toksynonakopychennya dlya CLOSTRIDIUM CHAUVOEI” No 60761 A. 2003021398, 10. 15.10.2003, Byul. No 10. http://uapatents.com/260761-seredovishhe-toksinonakopichennya-dlyaclostridium-chauvoei.html (in Ukrainian).

Bojko, P.K. (2008). Epizootologichnyj monitoryng. Klostrydiozy tvaryn. Emfizematoznyj karbunkul. Veterynarna medycyna Ukrayiny, 4, 8-10 (in Ukrainian).

Bojko, P.K. (2009). Epizootychnyi proces ta specyfichna profilaktyka emfizematoznogo karbunkulu velykoyi rogatoyi xudoby. Avtoref. dysertaciyi ... doktora veterynarnyx nauk. K.: NUBiP (in Ukrainian).

Bojko, P.K., Akymenko, L.I., Kovalenko, L.V., \& Bojko, O.P. (2008). Vidbir perspektyvnykh shtamiv Slostrid- ium chauvoei dlya deponuvannya u depozytariyi DNKIBShM. Veterynarna biotexnologiya. Materialy konferenciyi, prysvyachenoyi 10-richchyu stvorennya DNKIBShM. K.: DNKIBShM, Byuleten, 13(1), 223230 (in Ukrainian).

Busol, V.O., Ryzhenko, V.P., Mandygra, M.S., \& Bojko, P.K. (2005). Diagnostyka emfizema-toznogo karbunkulu: Metodychni rekomendaciyi dlya specialistiv vet. medycyny, naukovciv ta studentiv. K.: DDVM (in Ukrainian).

Chandler, H.M., \& Gulasekharam, J. (1974). The protective antigen of a highly immunogenic strain of Clostridium chauvoei inCluding an evaluation of its flagella as a protective antigen. J. Gen. Microbial., 84(1), 128-134. doi: 10.1099/00221287-84-1-128.

Derzhavnyj standart Ukrayiny 7198:2010. Preparaty veterynarni. Nalezhna laboratorna praktyka. Data vvedennya v diyu: 01.07.2011. Nadannya chynosti, nakaz: 2010-12-28, 604. Diye z 01.07.2011. [Elektronnyi resurs] Rezhy`m dostupu: http://document.ua/preparati-veterinarni_-nalezhnalaboratorna-praktika-std3688.html (in Ukrainian).

Derzhavnyj standart Ukrayiny 7199:2010. Preparaty veterynarni imunobiologichni. Nalezhna doklinichna praktyka. Data vvedennya v diyu: 01.07.2011. Komentar shhodo nadannya chynosti, nakaz: 2010-1228, 604. [Elektronnyi resurs] Rezhym dostupu: http://document.ua/preparati-veterinarniimunobiologichni_-nalezhna-doklinichnastd3689.html (in Ükrainian).

Derzhavnyj standart Ukrayiny 8164:2015. Preparatyveterynarni. Nalezhna vyrobnycha praktyka. Diye $\mathrm{z}$ 01.01.2017. Informaciya pro DSTU 8164:2015: Nadano chynnosti: nakaz DP "UkrNDNCz" vid 22 chervnya 2015, 61. [Elektronnyi resurs] Rezhym dostupu: http://document.ua/preparati-veterinarni_nalezhna-virobnicha-praktika-nor29321.html (in Ukrainian).

Derzhavnyj standart Ukrayiny 8492:2015. Veterynarna medycyna. Metody laboratornogo diagnostuvannya klostrydioziv. Data vvedennya v diyu: 01.07.2017. Komentar shhodo nadannya chynosti, nakaz: 2015-1021, 133. [Elektronnyi resurs] Rezhym dostupu: http://document.ua/veterinarna-medicina_-metodilaboratornogo-diagnostuvannja-k-std31238.html (in Ukrainian).

Derzhavnyj standart Ukrayiny ISO 7218:2014. Mikrobiologiya xarchovyx produktiv i kormiv dlya tvaryn. Zagalni nastanovy shhodo mikrobiologichnyx doslidzhen.Data vvedennya v diyu: 01.01.2016. Komentar shhodo nadannya chynosti, nakaz: 2014-1230, 1494. [Elektronnyj resurs] Rezhym dostupu: http://document.ua/mikrobiologija-harchovihproduktiv-i-kormiv-dlja-tvarin_-zag-std30622.html (in Ukrainian).

Derzhavnyj standart Ukrayiny ISO 7937:2006. Mikrobiologiya kharchovyx produktiv i kormiv dlya tvaryn. Goryzontalnyj metod vyznachennya kilkosti Clostridium Perfringens. Tekhnika pidrakhuvannya kolonij. Data vvedennya v diyu: 01.10.2007. Komentar shhodo 
nadannya chynosti, nakaz: 2006-06-09, 161. [E1ektronnyi resurs] Rezhym dostupu: http://document.ua/mikrobiologija-harchovih-

produktiv-i-kormiv-dlja-tvarin_-gor-std10402.html (in Ukrainian).

Galuzevyj standart Ukrayiny (2002). Preparaty veterynarni. Metody vyznachennya neshkidlyvosti [Tekst]: GSTU 46.024-2002. Vyd. oficz. Vpershe; vved. 200301-01. K.: [Elektronnyi resurs] Rezhy'm dostupu: https://zakon.rada.gov.ua/rada/show/v037155502?lang=ru (in Ukrainian).

Kagan, F.Y., \& Kyryllov, V.L. (1976). Specyficheskaya profilaktika klostrydiozov zhyvotnykh. M.: Kolos (in Russian).

Kyryllov, L.V. (2001). Preduprezhdenie o infekcionnykh boleznej anaerobnoj etiologii. Veterinariya, 1, 16-19 (in Russian).

Logosha, R.V. (2012). Myasne skotarstvo Ukrayiny: stan, tendenciyi ta napryamky jogo intensyfikaciyi. Zbirny`k naukovyx pracz VNAU. Seriya: Ekonomichni nauky, 2, 1(56), 90-96 (in Ukrainian).

Mandygra, M.S. Bojko, P.K., \& Bojko, O.P. (2003). Osoblyvosti epizootychnogo procesu pry emfizema- toznomu karbunkuli velykoyi rogatoyi khudoby $\mathrm{v}$ Ivano-Frankivs'kij oblasti. Veterynarna medycyna (mizhvidomchyj tematychnyj naukovyj zbirnyk), 82, 376-380 (in Ukrainian).

Mandygra, M.S., Bojko, P.K., \& Bojko, O.P. (2015). Metodychni pidkhody do konstruyuvannya bakterialnykh vakcyn na prykladi inaktyvovanykh vakcyn proty emfizematoznogo karbunkulu. Vet. medycyna: Mizhvid. temat. nauk. zb., Kh., 101, 211-214 (in Ukrainian).

Misra, R.P. (1991). Manual for the production of anthrax and blackleg vaccines. Fao animal production and health paper, 87. http://www.fao.org/3/T0278E/T0278E00.htm.

Tamura, Y., Minamoto, N., \& Tanaka, S. (1984). Demonstration of protective antigen carried by flagella of Clostridium chauvoei. Microbial. Immunol., 28(2), 13251332. doi: 10.1111/j.1348-0421.1984.tb00790.x.

Tanaka, M., Hirayama, N., \& Tamura, Y. (1987). Production, characterization and protective effect of monoclonal antibodies to Clostridium chauvoei flagella. Infect. Immun., 55, 1779-1783. https://www.ncbi.nlm.nih.gov/pubmed/3301677. 